\title{
Ablation of Perk in Schwann Cells Improves Myelination in the S63del Charcot-Marie-Tooth 1B Mouse
}

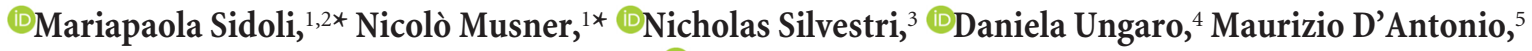 \\ Douglas R. Cavener, ${ }^{6}$ M. Laura Feltri, ${ }^{1,2,3}$ and ${ }^{-}$Lawrence Wrabetz ${ }^{1,2,3}$ \\ ${ }^{1}$ Hunter James Kelly Research Institute and Departments of ${ }^{2}$ Biochemistry and ${ }^{3}$ Neurology, Jacobs School of Medicine and Biomedical Sciences, University \\ at Buffalo, Buffalo, New York 14203, Divisions of ${ }^{4}$ Neuroscience and ${ }^{5} \mathrm{Genetics}$ and Cell Biology, San Raffaele Scientific Institute, DIBIT, Milan, Italy 20132, \\ and ${ }^{6}$ Department of Biology, Center for Cellular Dynamics, Pennsylvania State University, University Park, Pennsylvania 16802
}

In factory cells, the accumulation of misfolded protein provokes the unfolded protein response (UPR). For example, deletion of serine 63 (S63del) in myelin protein zero ( $\mathrm{P0}$ ) induces $\mathrm{P} 0$ accumulation in the endoplasmic reticulum (ER) of Schwann cells and a persistent UPR associated with Charcot-Marie-Tooth 1B (CMT1B) demyelinating peripheral neuropathy in human and mouse. PERK (protein kinase RNA-like ER kinase) is the ER stress sensor that attenuates global translation by phosphorylating eIF2 $\alpha$. Inhibition of the eIF2 $\alpha$ holophosphatase GADD34:PP1, increases the phosphorylation of eIF2 $\alpha$ in Schwann cells and largely rescues S63del neuropathy. Nonetheless, reducing phosphorylation of eIF2 $\alpha$, by Perk haploinsufficiency, also ameliorates the myelin defects of S63del nerves. This contradictory finding prompted us to investigate whether the beneficial effect of Perk deficiency on myelination could derive from neurons. To test this hypothesis, we generated and compared Schwann cell- and neuron-specific ablation of Perk in S63del nerves. Our data suggest that the detrimental effect of Perk in CMT1B derives primarily from Schwann cells. Furthermore, we show that Perk loss of function in Schwann cells restores myelination without diminishing accumulation of P0 or markers of ER stress, suggesting that Perk may modulate myelination through a pathway independent of the UPR.

Key words: Charcot-Marie-Tooth; myelin; PERK; proteostasis; Schwann cells; unfolded protein response

\section{Significance Statement}

In many endoplasmic reticulum (ER) stress-related disorders, activation of the unfolded protein sensor protein kinase RNA-like ER kinase (PERK) kinase is beneficial. Nonetheless, in Charcot-Marie-Tooth $1 \mathrm{~B}$ neuropathy mice, we show that activation of PERK in Schwann cells, but not in neurons, is detrimental for myelination. PERK may interfere with myelination, independent of its role in ER stress.

\section{Introduction}

Myelin is a multilayered structure that protects axons and maintains the speed of electrical impulses along peripheral nerves

\footnotetext{
Received May 21, 2016; revised Aug. 3, 2016; accepted Aug. 9, 2016.

Author contributions: M.S., N.M., M.D., D.R.C., M.L.F., and L.W. designed research; M.S., N.M., N.S., and D.U. performed research; M.D. contributed unpublished reagents/analytic tools; M.S., N.M., M.L.F., and L.W. analyzed data; M.S. and L.W. wrote the paper.

This work was supported by grants from the National Institutes of Health (R56NS096104 to L.W.; R01NS045630 to M.L.F.); Telethon, Italy (GGP071100 to L.W.; GGP08021 to M.L.F.); the European Community (FP7/2007-1013 under Grant Agreement HEALTH-F2-2008-201535 to L.W. and M.L.F.); and the Charcot Tooth Marie Association (L.W.). M.D. is the recipient of a Giovane Ricercatore Award from the Italian Ministry of Health (GR-2009-1548255). We thank GianGiacomo Conzalez for the NestinCre mice. We thank Stefania Saccucci, Desiree Zambroni, and Georgia Dina at San Raffaele Scientific Institute and Annette Featherstone of the South Campus Histology Core Facility, University at Buffalo, for excellent technical assistance.

*M.S. and N.M. contributed equally to this work.

The authors declare no competing financial interests.

Correspondence should be addressed to Lawrence Wrabetz, Jacobs School of Medicine and Biomedical Sciences, University at Buffalo, 701 Ellicott Street, Buffalo, New York 14203. E-mail: Iwrabetz@buffalo.edu.

N. Munser's present address: AB ANALITICA s.r.l., Via Svizzera 16, 35127 Padova, Italy.
}

(Sherman and Brophy, 2005). Schwann cells are the myelinating glia of the peripheral nervous system (PNS) and produce an enormous amount of proteins daily, among which myelin protein zero (P0) accounts for 20\% (Patzig et al., 2011). Thus, myelinating Schwann cells require an efficient protein quality control to address translational burden. Deletion of serine 63 in $\mathrm{P} 0$ protein (P0S63del) causes Charcot-Marie-Tooth 1B (CMT1B) demyelinating neuropathy, which is characterized by demyelination, reduction in nerve conduction velocity, and motor impairment (Kulkens et al., 1993; Wrabetz et al., 2006; Miller et al., 2012). P0S63del protein is retained in the endoplasmic reticulum (ER) and triggers the unfolded protein response (UPR), which is pathogenetic in S63del neuropathy (Pennuto et al., 2008; D'Antonio et al., 2013).

The UPR restores cellular homeostasis by reducing the amount of aberrant proteins that accumulate in the ER (Schröder and Kauf- 
man, 2005; Walter and Ron, 2011). The UPR is intermittently active and protective in physiological conditions. However, when it becomes persistent, the UPR can activate maladaptive effectors involved in cell death and dedifferentiation (Tabas and Ron, 2011; Hetz et al., 2013). Three ER stress sensors initiate the UPR pathways: the inositol-requiring protein-1 (IRE1), activating transcription factor-6 (ATF6), and protein kinase RNA-like ER kinase (PERK). Upon activation, IRE1 mediates the splicing of $X$-box binding protein 1 (Xbp1) mRNA (Bertolotti and Ron, 2001; Yoshida et al., 2001; Calfon et al., 2002). In mammals, XBP1s reprograms the transcription of genes involved in protein folding, degradation, and ER biogenesis (Friedlander et al., 2000; Travers et al., 2000; Lee et al., 2003; Yoshida et al., 2003; Sriburi et al., 2004). The ATF6 pathway promotes the expression of ER resident chaperones (Haze et al., 1999; Yoshida et al., 2000; Shen et al., 2002). Finally, PERK kinase phosphorylates the eukaryotic translation initiation factor $2 \alpha(\mathrm{eIF} 2 \alpha)$ on Ser51 (Harding et al., 1999), which causes a global attenuation of protein translation, and thereby limits the accumulation of client proteins in the ER (Harding et al., 2000b).

Upon persistent stress, PERK-dependent eIF $2 \alpha$ phosphorylation is beneficial for professional secretory cells; accordingly, Perk loss of function results in reduced numbers of differentiated pancreatic $\beta$ cells or osteoblasts (Harding et al., 2000b, 2001b; Zhang et al., 2002, 2006; Wei et al., 2008). Downstream of PERK, growth arrest and DNA damage-inducible protein (GADD34):PP1 holophosphatase reduces eIF $2 \alpha$ phosphorylation to limit translational arrest (Novoa et al., 2001). We have shown that loss of Gadd34 increases eIF2 $\alpha$ phosphorylation and almost completely rescues S63del neuropathy (D’Antonio et al., 2013; Das et al., 2015). Nonetheless, Perk haploinsufficiency paradoxically also ameliorates the neuropathy of the CMT1B mouse model, despite that the levels of phosphorylated eIF $2 \alpha$ (P-eIF2 $\alpha$ ) were significantly reduced (Musner et al., 2016).

These surprising results prompted us to investigate in S63del nerves whether the beneficial effect of Perk loss of function was Schwann cell or neuron autonomous. In this study, we demonstrate that Perk ablation in Schwann cells, but not in neurons, partially restores myelination in S63del nerves. The defects of S63del myelination are improved despite that $\mathrm{P} 0$ accumulates considerably in the ER, and the UPR markers remain upregulated. Our data suggest that the UPR may not be the only pathogenetic mechanism contributing to the S63del/CMT1B neuropathy. PERK may also perturb other pathways outside of the UPR.

\section{Materials and Methods}

Mice. All experiments involving mice were performed in accord with the experimental protocols approved by the San Raffaele Scientific Institute, and Roswell Park Cancer Institute, and the University at Buffalo Institutional Animal Care and Use Committees. P0S63del transgenic mice include the S63del-L (129.4) transgenic line, overexpressing mutant MpzS63del mRNA by $60 \%$, and the S63del-H (129.1) transgenic line, overexpressing mutant MpzS63del mRNA by $210 \%$; Wrabetz et al., 2000, 2006). Mice containing Perk flanked by loxP conditional allele (Perk ${ }^{\mathrm{f} /+}$ mice; Zhang et al., 2002) were crossed with $\mathrm{mP}_{0}$ TOTA-Cre (P0Cre) mice (Feltri et al., 1999) and S63del mice, to obtain P0Cre/Perk ${ }^{\mathrm{f} /+}$ and S63del/ Perk $^{\mathrm{f} /+}$ breeders. Parents coming from these crosses were mated to generate S63del/P0Cre/Perk ${ }^{\mathrm{f} / \mathrm{f}}$ (S63del/Perk ${ }^{\mathrm{SCKO}}$ ) and S63del/P0Cre/ $\mathrm{Perk}^{\mathrm{f} /+}\left(\mathrm{S} 63 \mathrm{del} / \mathrm{Perk}^{\mathrm{SCHet}}\right)$ and all other control genotypes within the same litter. To remove Perk from neurons, Perk floxed, NestinCre (Zimmerman et al., 1994; Tronche et al., 1999), and S63del mice were crossed, using the same mating strategy as for P0Cre to generate S63del/NestinCre/Perk ${ }^{\mathrm{f} / \mathrm{f}}$ (S63del/Perk $\left.{ }^{\mathrm{NRNKO}}\right)$ and control littermates. Chop-null mice (Zinszner et al., 1998) were used as controls and have been described previously. P0Cre, NestinCre, Perk ${ }^{\mathrm{f} /+}$, and S63del-L mice were maintained on a C57BL/6NCrl background; S63del-H and Chop-null mice were maintained on an FVB/NCrl background. Male and female litter- mates were analyzed in all experiments. All genotypes were determined by PCR analysis of genomic DNA prepared from tail samples as described in the references above. Cre recombination PCR assays were performed on genomic DNA prepared from postnatal day 28 (P28) tissues with primer pairs generating $400 \mathrm{bp} \mathrm{WT}, 480 \mathrm{bp}$ loxP, and $700 \mathrm{bp}$ recombined loxP amplimers. PCR primers and conditions were as described previously (Zhang et al., 2002).

Morphology and electrophysiology. For electrophysiology, mice were anesthetized with $20 \mathrm{mg} / \mathrm{ml}$ of tribromoethanol (Avertin), $0.02 \mathrm{ml} \mathrm{g}^{-1}$ of body weight. Nerve conduction velocity (NCV), F-wave latency, and distal motor action potential (CMAP) amplitude were analyzed at P28 as described previously (Wrabetz et al., 2006). Semithin section and electron microscopy were performed as described previously (Quattrini et al., 1996). Images for $g$ ratio (axon diameter/fiber diameter), axonal distribution, and number of amyelinated fibers were acquired with a $100 \times$ objective on a Leica DM 6000 microscope. Quantification was performed on four semithin images per sciatic nerve, $1200-1300$ fibers in 12 fields for each genotype from WT, Perk ${ }^{\mathrm{SCKO}}$, S63del, and S63del/ Perk $^{\text {SCKO }}$ P28 sciatic nerves. The $g$ ratio was measured using the Leica QWin software. Data were analyzed using GraphPad Prism, version 6.01. Ultrastructural images were acquired on an FEI Tecnai G2 Spirit BioTWIN electron microscope.

Western blot analysis. Sciatic nerves from P28 mice were dissected and frozen in liquid nitrogen. Proteins were extracted in RIPA buffer $(50 \mathrm{~mm}$ Tris $\mathrm{HCl}, \mathrm{pH}$ 8.0, $150 \mathrm{~mm} \mathrm{NaCl}, 1 \% \mathrm{NP}-40,0.5 \%$ sodium deoxycholate, $0.1 \%$ SDS, 1 mm sodium orthovanadate, protease inhibitors; Krackeler). Lysates were sonicated and centrifuged at $13,200 \mathrm{rpm}$ for $10 \mathrm{~min}$ at $4^{\circ} \mathrm{C}$. Twenty micrograms of protein were resolved in SDS-polyacrylamide gel and blotted on PVDF membrane (PerkinElmer, GE Healthcare, Odyssey detection system). For the detection of phospho-IRE1 (P-IRE1), we used Phos-Tag $(25 \mu \mathrm{M})$ acrylamide gel as described previously (Yang et al., 2010). Membranes were probed overnight with the following antibodies: rabbit poly-sera (Rb pAb) recognized $\alpha$-tubulin (1:2000; Novus Biologicals), calnexin and GAPDH (Sigma, 1:2000), P-eIF2 $\alpha$ (Cell Signaling Technology, 1:500), CCAAT/enhancer-binding homologous protein (CHOP) (Proteintech, 1:500), IRE1 $\alpha$ (Cell Signaling Technology, 1:1000), activating transcription factor 4 (ATF4; Santa Cruz Biotechnology, 1:200), ATF6 (Enzo Life Sciences, 1:1000), and Rb mAb recognized PERK (Cell Signaling Technology, 1:1000). Membranes were incubated with HRP conjugated secondary antibodies against rabbit (DAKO, 1:5000). Rb pAb against calreticulin (Enzo Life Sciences, 1:1000), GRP78 (Novus Biologicals, 1:1000), GADD34 (Proteintech, 1:500), and rat mAb GRP94 (Abcam, 1:1000) were detected with the Odyssey CLx infrared imaging system (Li-Cor). IRDye 680 anti-mouse, 800 anti-rabbit, and 680 anti-rat were used as secondary antibodies (Li-Cor, 1:10,000). The densitometry was performed with ImageJ-64 software.

Immunohistochemistry. Spinal cord from Perk ${ }^{\mathrm{NRNKO}}$ and sciatic nerves from P28 Perk ${ }^{\mathrm{SCKO}}$ were fixed overnight in $10 \%$ formalin buffer (Thermo Fisher Scientific). Tissues were infiltrated in sucrose (scale, $10-20-30 \%$; 20 min each) and embedded in paraffin. Paraffin was removed from 1- to $2-\mu \mathrm{m}$-thick sections with three washings in xylene (Thermo Fisher Scientific; 10 min each) and ethanol (scale, 100-90-70\%; $1 \mathrm{~min}$ each). Spinal cord sections were soaked in citrate buffer, $\mathrm{pH} 6.0$ $\left(95^{\circ} \mathrm{C}\right.$ for $\left.15 \mathrm{~min}\right)$, whereas sciatic nerve sections were immersed in TrisEDTA, pH 9.0, buffer in an $87^{\circ} \mathrm{C}$ water bath for antigenic retrieval. Sections were washed in $10 \% \mathrm{H}_{2} \mathrm{O}_{2}$ to block endogenous peroxidases, and were blocked with normal goat serum (Covance) for $20 \mathrm{~min}$ at room temperature. Sections were probed for $1 \mathrm{~h}$ with antibody against PERK (Lifespan, 1:500) in blocking buffer, followed by HRP-conjugated secondary antibody (DAKO Envision System-HRP) for $30 \mathrm{~min}$ at room temperature and diaminobenzadine (DAB) chromogen for $1 \mathrm{~min}$ at room temperature to reveal PERK. Finally, sections were counterstained with hematoxylin.

Immunofluorescence. P28 sciatic nerves from WT, Perk ${ }^{\mathrm{SCKO}}, \mathrm{S} 63 \mathrm{del}$, and $563 \mathrm{del} /$ Perk ${ }^{\mathrm{SCKO}}$ mice were fixed in $4 \%$ ice cold paraformaldehyde for $30 \mathrm{~min}$ before teasing on 3\% 3-aminopropyl triethoxysilan-coated slides. Nerves were postfixed in $4 \%$ ice-cold paraformaldehyde for 15 min, permeabilized in cold methanol for $5 \mathrm{~min}$, and blocked in 5\% fish skin gelatin (Sigma), $0.5 \%$ Triton X-100 in $1 \times$ PBS. Slides were incu- 
bated overnight with mouse antibody against KDEL (Enzo Life Sciences, 1:200) and chicken anti P0 (Aves, $1: 300$ ) in $0.2 \%$ Triton X-100/1 $\times$ PBS. After washing the primary antibodies in $1 \times$ TBS, the slides were incubated for $1 \mathrm{~h}$ at room temperature with Jackson ImmunoResearch Alexa Fluor 594 secondary antibodies against mouse IgG sub2a and Alexa Fluor 488 secondary antibodies against chicken IgY (1: 400). 4',6-Diamidino-2-phenylindole (DAPI) was used to reveal nuclei. Adult dorsal root ganglia (DRGs) were dissected from P28 WT and Perk ${ }^{\text {NRNKO }}$ mice and fixed in $4 \%$ ice cold paraformaldehyde for $30 \mathrm{~min}$ on ice. DRGs were then washed in $1 \times$ PBS and left in 30\% sucrose for at least $24 \mathrm{~h}$ at $+4^{\circ} \mathrm{C}$ before embedding in tissue freezing media (OCT). After sectioning the DRGs $(8 \mu \mathrm{m}), 4 \%$ ice cold paraformaldehyde was applied for $15 \mathrm{~min}$, and then acetone at $-20^{\circ} \mathrm{C}$ for $5 \mathrm{~min}$. DRGs were incubated overnight with the following primary antibodies: rabbit against phosphoeIF2 $\alpha$ (Ser51; Cell Signaling Technology, 1:400) and mouse sub2a against Tuj-1 (BioLegend; $1: 600)$ in blocking solution (5\% filtered BSA, $1 \%$ donkey serum, and $0.2 \%$ Triton $\mathrm{X}-100$ in $1 \times \mathrm{TBS})$ at $+4^{\circ} \mathrm{C}$. Donkey secondary antibodies from Jackson ImmunoResearch against rabbit (Alexa Fluor 488) and against mouse IgG sub2a (Alexa Fluor 647) were used to finally reveal the staining. Pictures were acquired with the $100 \times$ objective of the Leica confocal TCS SP 5 microscope for sciatic nerve and the $20 \times$ objective for adult DRGs. P0 pixel intensity within the KDEL area was quantified using ImageJ64 software as described previously (Fratta et al., 2011).

RNA isolation and TaqMan quantitative PCR. RNA was isolated from P28 sciatic nerves using TRIzol reagent (Invitrogen), following the manufacturer's instructions. Briefly, pairs of nerves from single mice were pulverized in liquid nitrogen and added to $800 \mu \mathrm{l}$ of TRIzol. Chloroform (160 $\mu \mathrm{l}$ ) was added to the lysates and centrifuged at $12,000 \times \mathrm{g}$ for $15 \mathrm{~min}$ at $4^{\circ} \mathrm{C}$. The aqueous phase was then placed overnight with $500 \mu \mathrm{l}$ of isopropanol and $1 \mu \mathrm{l}$ of glycogen $(20 \mathrm{mg} / \mathrm{ml})$. Pellets were collected by centrifugation at $12,000 \times \mathrm{g}$ for $10 \mathrm{~min}$ at $4^{\circ} \mathrm{C}$ and washed twice in $75 \%$ ethanol at $7500 \times \mathrm{g}$ for $15 \mathrm{~min}$. One microgram of RNA was retrotranscribed to cDNA using the Superscript III kit (Invitrogen) following the manufacturer's instructions. TaqMan PCR analyses were performed on the Bio-Rad CFX96/384 real-time PCR machine. The PCRs for the target and reference genes were performed in separate test tubes with Assays-on-Demand (Applied Biosystems): Ddit3/ Chop, Mm00492097_m1; Myd116/Gadd34, Mm00435119_m1; Xbp1s, Mm03464496_m1; Dnajc3/p58 ${ }^{I P K}$, Mm00515299_m1; Dnajb9/ERdj4, Mm01622956_s1;Hspa5/BiP,Mm00517691_m1;Derl3/Derlin3,Mm00508292_ m1; Car6/Doc1, Mm00486222_m1. Normalization was performed using rRNA 18s, Hs99999901_s1. Littermates were analyzed, and every genotype was compared to the WT of the same cohort.

Statistical analysis. All statistical analysis was conducted using GraphPad Prism, version 6.01. In every experiment, at least three biological replicates were analyzed. To determine the significance between genotypes, Student's $t$ test or one-way ANOVA was used. A value of $p \leq 0.05$ was considered statistically significant. Graphical data are represented as mean \pm SEM.

\section{Results}

Genetic ablation of Perk in S63del Schwann cells

Although Gadd34 impairment and increased levels of P-eIF2 $\alpha$ are beneficial in S63del nerves (D’Antonio et al., 2013; Das et al., 2015), Perk haploinsuffiency and reduced P-eIF2 $\alpha$ levels in nerves are par- adoxically also beneficial in S63del mice (Musner et al., 2016). To investigate whether this contradiction results from effects of P-eIF2 $\alpha$ in different cells in peripheral nerve in the two experiments, we exploited a conditional allele of Perk (Zhang et al., 2002) to produce mice lacking Perk in either Schwann cells or neurons.

To target ablation of Perk to Schwann cells, we crossed Perk fl+ $^{f /+}$ mice (Zhang et al., 2002) with those with a P0Cre recombinase transgene to obtain P0Cre/Perk ${ }^{\mathrm{f} / \mathrm{f}}$ mice (hereafter Perk ${ }^{\mathrm{SCKO}}$ ). P0Cre activates recombination in all Schwann cells beginning at embryonic day 13.5 (Feltri et al., 1999). We then bred S63del onto the Perk ${ }^{\mathrm{SCKO}}$ background to obtain S63del/Perk ${ }^{\mathrm{SCKO}}$ mice.

To test the efficiency and specificity of the P0Cre, we analyzed the recombination of the Perk ${ }^{\operatorname{lox} P}$ allele by PCR assays in genomic DNA from WT, Perk ${ }^{\mathrm{SCH}}$, and Perk ${ }^{\mathrm{SCKO}}$ tissues (Fig. 1A). The Perk WT band appeared in all WT and Perk ${ }^{\mathrm{SCHet}}$ samples, whereas the nonrecombined Perk loxP band appeared in Perk ${ }^{\text {SCHet }}$ as expected, but also in Perk ${ }^{\mathrm{SCKO}}$ samples, due to cells other than Schwann cells in nerve. The 700 bp recombination band (Zhang et al., 2002) appeared only in sciatic nerves from Perk ${ }^{\mathrm{SCHet}}$ and Perk ${ }^{\mathrm{SCKO}}$ mice, whereas it was not detected in brain, liver, kidney, muscle, or spinal cord samples (Fig 1A). Accordingly, PERK protein was almost absent from S63del/Perk ${ }^{\text {SCKO }}$ sciatic nerve lysates (Fig $1 B$ ). Moreover, immunohistochemistry on cross-sections of sciatic nerves revealed that PERK cytoplasmic staining was notably reduced in Schwann cells from Perk ${ }^{\mathrm{SCKO}}$ mice (Fig. $1 C$, arrowheads). This evidence suggests that P0Cre efficiently removed PERK from myelinating Schwann cells. 
A

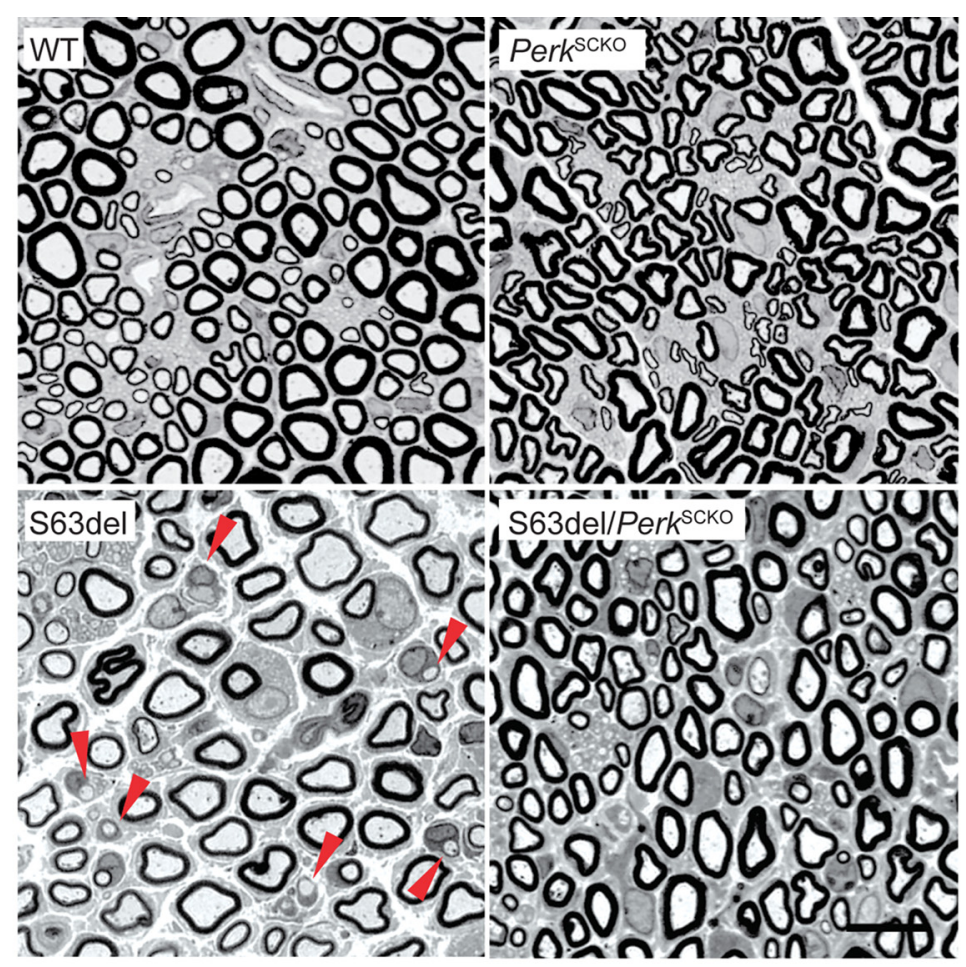

B
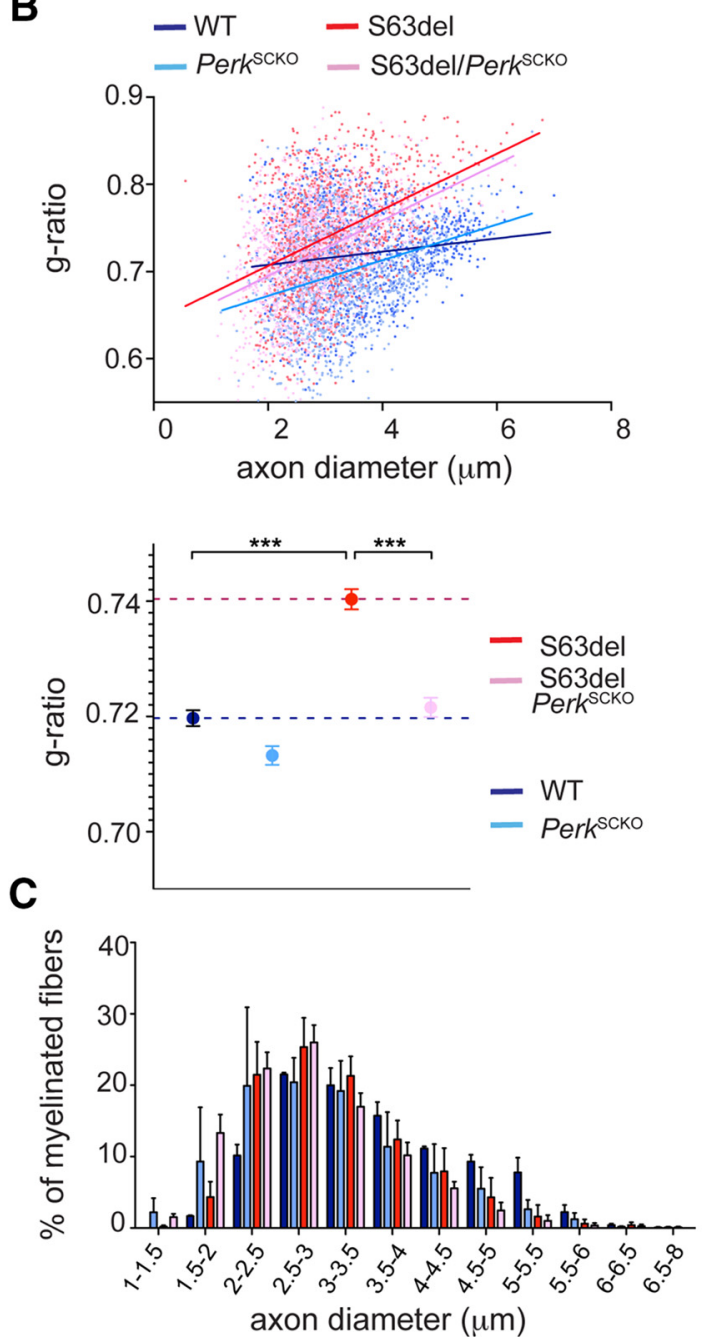

D

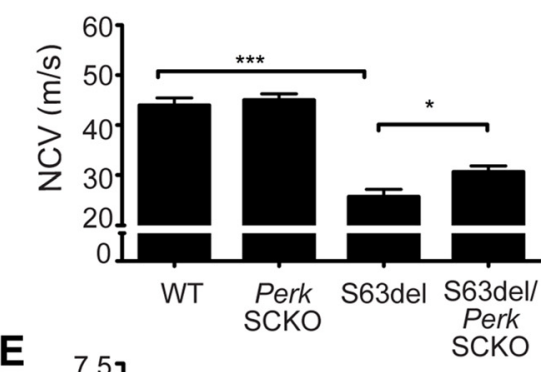

E
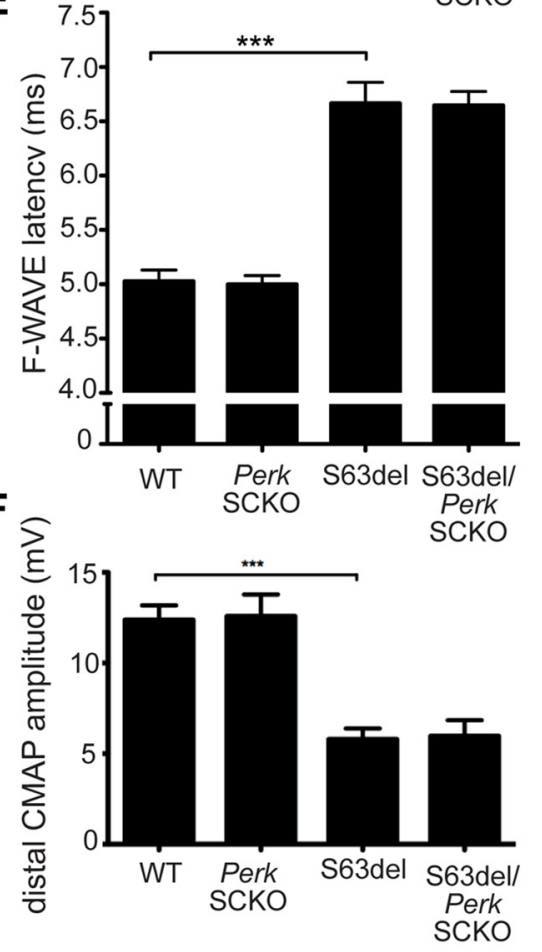
A


B
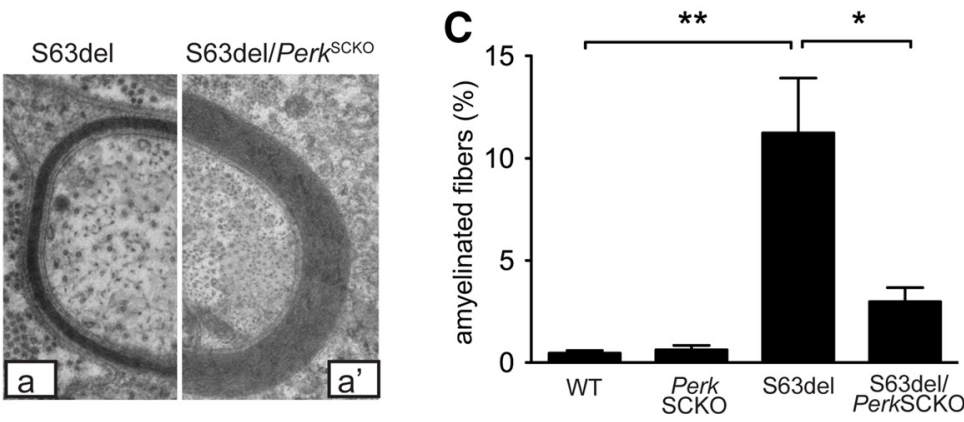

Figure 3. Perk ablation decreases the number of amyelinated fibers in S63del nerves. $A$, Electron microscopy shows hypomyelination, especially in small caliber axons (pseudocolored blue), of S63del compared to WT sciatic nerves at P28. In S63del/Perk ${ }^{\text {SCK0 }}$ compared to S63del, myelin of small caliber axons appears thicker. Scale bar, $2 \mu \mathrm{m}$. B, Axons with similar diameter were magnified

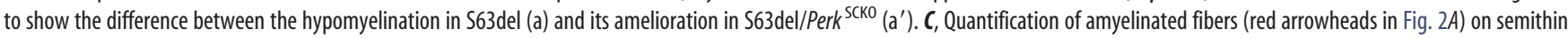
sections of P28 sciatic nerves. Error bars indicate SEM. ${ }^{*} p<0.01 ;{ }^{* *} p<0.001$ (one-way ANOVA with Bonferroni multiple comparison; 5 microscopic fields from 3 animals per genotype).

Perk ablation in Schwann cells improves S63del neuropathy Schwann cells highly express P0 and P0S63del mRNA and protein at P28 (Wrabetz et al., 2006) and persistently activate PERK, which has detrimental effects in nerve (Musner et al., 2016). To confirm that PERK in Schwann cells contributes to the detrimental effect, we performed morphological analysis in P28 in Perk ${ }^{\mathrm{SCKO}}$ and $\mathrm{S} 63 \mathrm{del} /$ Perk $^{\mathrm{SCKO}}$ nerves. As shown previously, S63del nerves manifested hypomyelination compared to WT, as shown by semithin section (Fig. $2 A$ ) and $g$ ratio analyses (Fig. $2 B$; $0.74 \pm 0.02$ in S63del vs $0.72 \pm 0.01$ in WT). Perk elimination in WT Schwann cells did not significantly alter myelination; however, its elimination in S63del Schwann cells returned myelin thickness to WT levels as measured by $g$-ratio analysis (Fig. $2 B$; $0.72 \pm 0.02$ in $\mathrm{S} 63 \mathrm{del} /$ Perk $^{\mathrm{SCKO}}$ vs $0.72 \pm 0.01$ in WT).

We noticed a slight shift toward smaller axon diameters in S63del compared to WT nerves, consistent with a secondary reduction of neurofilament phosphorylation due to mild hypomyelination (Fig. 1C; de Waegh et al., 1992). Interestingly, the number of the smallest myelinated fibers (1-2 $\mu \mathrm{m}$ in diameter) rose sharply in S63del/Perk ${ }^{\mathrm{SCKO}}$ compared to S63del nerves (Fig. $2 C$, compare pink, red bars). More generally, electron microscopic analysis confirmed the increment of myelin thickness in S63del/Perk ${ }^{\mathrm{SCKO}}$ compared to S63del nerves (Fig. 3A; axons

\footnotetext{
Figure 2. Perk ablation in Schwann cells ameliorates morphological and electrophysiological abnormalities in S63del mice. A, Semithin sections of P28 sciatic nerve stained with toluidine blue from WT, Perk ${ }^{\mathrm{SCK} 0}$, S63del, and S63del/Perk ${ }^{\mathrm{SCK} 0}$ mice. S63del nerves show evidence of amyelinated fibers (red arrowheads). Scale bar, $10 \mu \mathrm{m} . \boldsymbol{B}, g$ ratio analysis (scatterplot above and graph below) confirmed hypomyelination in S63del (red) versus WT (blue) nerves, whereas in $563 \mathrm{del} /$ Perk ${ }^{\mathrm{SCKO}}$ (pink) nerves, myelin returns to WT thickness. ${ }^{* * *} p<0.01$ (one-way ANOVA with Bonferroni correction; 5 microscopic fields from 3 animals containing $n=1000-1200$ fibers per genotype). C, Frequency distribution of myelinated axons as a function of axonal diameter shows that Perk ablation from S63del Schwann cells (pink) restores myelination, especially in small caliber axons (1-2 $\mu \mathrm{m})$, compared to S63del (red). $\boldsymbol{D}-\boldsymbol{F}$, Electrophysiological analysis of P28 mouse sciatic nerve showing NCV $(\boldsymbol{D})$, F-wave latency $(\boldsymbol{E})$, and distal CMAP amplitude $(\boldsymbol{F}) .{ }^{*} p<0.05$; ${ }^{* * *} p<0.001$ (Student's $t$ test). $n=12-30$ nerves. Error bars indicate SEM.
}

pseudocolored blue), including in axons of equal diameter (Fig. $\left.3 B, a, a^{\prime}\right)$. The nerves of C57BL6/N-S63del mice contain a considerable number of amyelinated axons. These axons are not myelinated despite their 1:1 relationship with Schwann cells and appropriate diameter $(\geq 1 \mu \mathrm{m})$. In $\mathrm{S} 63 \mathrm{del} /$ Perk $^{\mathrm{SCKO}}$ nerves, the percentage of amyelinated fibers is reduced fourfold compared to S63del (Fig. 3C).

This improvement prompted us to investigate function. By electrophysiological analysis, we confirmed that NCV and distal CMAP amplitude were reduced (Fig. $2 D, F$ ), and F-wave latency was increased $(E)$ in S63del compared to WT P28 mice. S63del/Perk ${ }^{\text {SCKO }}$ nerves showed partially restored NCV compared to S63del (Fig. 2D), although the F-wave latency and distal CMAP amplitude did not differ between the two genotypes (Fig. $2 E, F)$. Collectively, these data demonstrate that Perk ablation in S63del Schwann cells surprisingly prevents the developmental myelin abnormalities of the S63del neuropathy. Therefore, the detrimental effect of PERK on myelination does originate at least in part from Schwann cells.

Perk ablation in neurons does not alter S63del myelin defects Perk haploinsufficiency surprisingly improved myelination and ameliorated the S63del phenotype (Musner et al., 2016). However, in the study by Musner et al. (2016), Perk was ablated in every cell type of the $\mathrm{S63del} \mathrm{mouse,} \mathrm{including} \mathrm{neurons.} \mathrm{More-}$ over, axons are also damaged as a secondary consequence of demyelination in S63del nerves (Wrabetz et al., 2006). Therefore, we reasoned that Perk ablation in neurons might account for the paradoxical amelioration observed in S63del/Perk ${ }^{+/-}$mice. In particular, we asked whether Perk deletion in neurons could limit either the myelin defects or the secondary axonal defects as observed in S63del/Perk ${ }^{\mathrm{SCKO}}$. We crossed Perk $^{f /+}$ mice with mice expressing Cre recombinase in neural cells in the CNS, including motor neurons, and DRG neurons in the PNS (NestinCre; Tronche et al., 1999) to obtain NestinCre/Perk ${ }^{\mathrm{f} / \mathrm{f}}$ mice (hereafter, Perk ${ }^{\mathrm{NRNKO}}$ ). In this way, all neurons that con- 


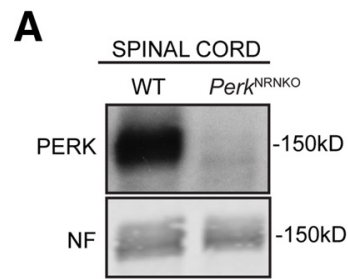

B

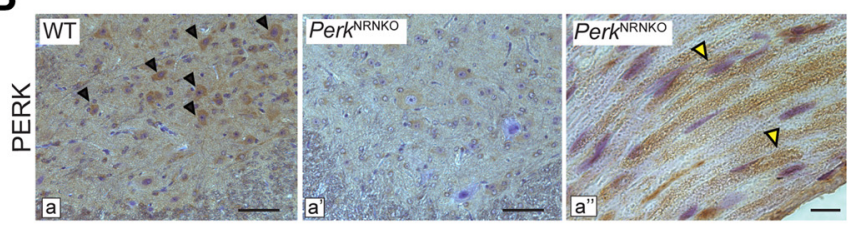

C
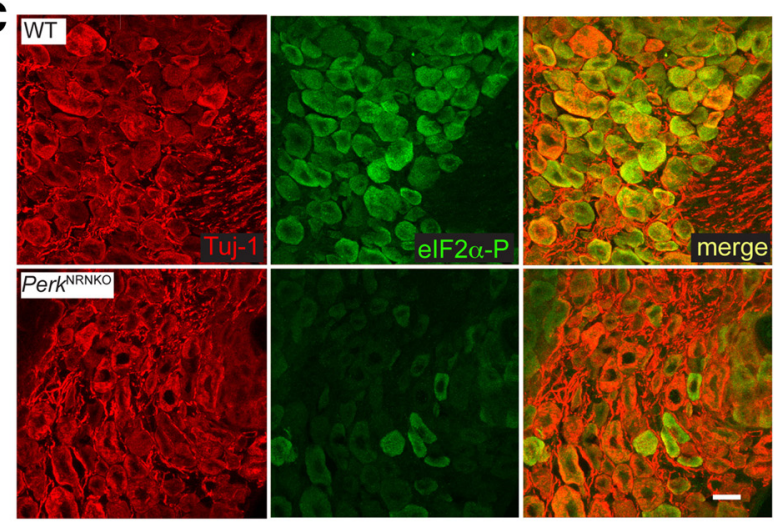

G
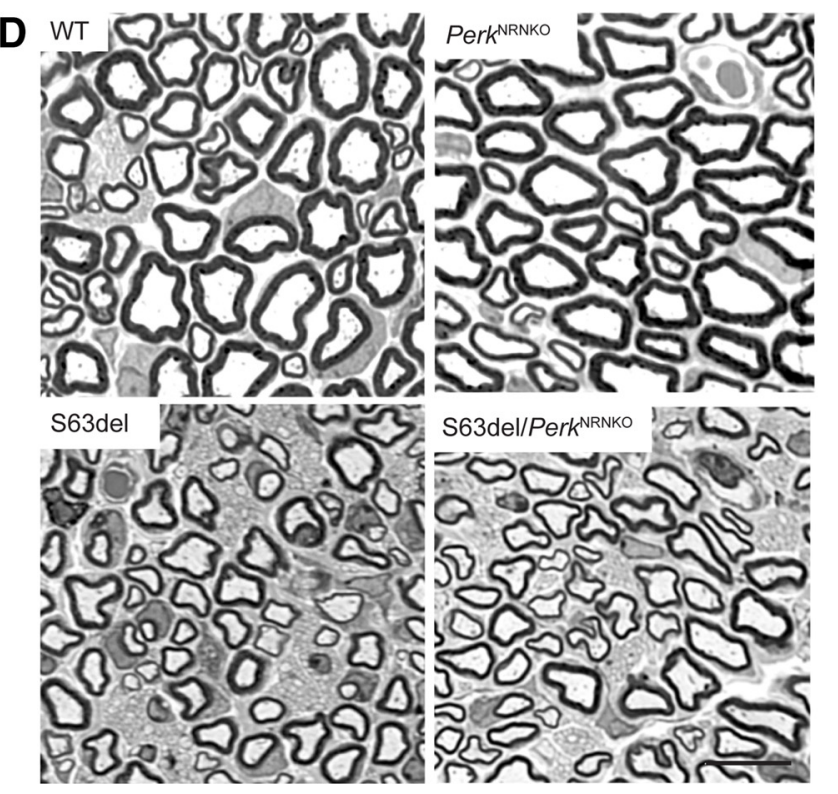

E
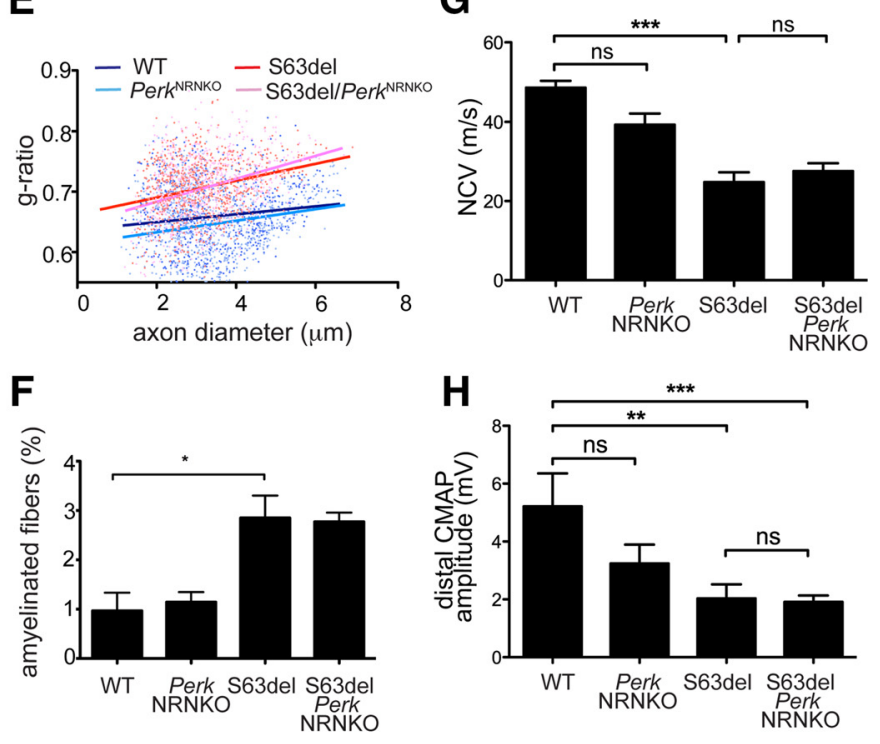

Figure 4. Genetic ablation of Perk in neurons does not alter myelination in S63del nerves. $\boldsymbol{A}$, PERK protein level was detected by Western blot analysis in whole lysates of spinal cord from P28 WT and Perk ${ }^{\text {NRNKO }}$ mice. Neurofilament (NF) served as a loading control. The quantification of Western blot analysis confirms the decrease of PERK protein level in Perk ${ }^{\text {NRNKO }}$ spinal cords. ${ }^{*} p<0.05$ (Student's $t$ test). $n=3 . \boldsymbol{B}$, Immuohistochemistry on P28 spinal cord (ventral horns) and longitudinal sections of sciatic nerve revealed PERK in the cell body of neurons ( $a$; black arrowheads indicate brown DAB precipitate) and Schwann cells ( $a^{\prime \prime} ;$ yellow arrowheads), whereas PERK intensity strongly decreases in Perk ${ }^{\text {NRNKO }}$ neurons ( $a^{\prime}$ ). Nuclei were counterstained with hematoxylin (blue). C, Immunofluorescence analysis on DRGs from P28 WT and Perk ${ }^{\text {NRNKO }}$ mice shows P-elF2 $\alpha$ (green) in cell bodies of sensory DRG neurons (Tuj-1; pseudocolored red). D, Semithin sections of sciatic nerves stained with toluidine blue from P28 WT, Perk ${ }^{\text {NRNKO }}$, S63del, and S63del/Perk ${ }^{\text {NRNK0 }}$ mice. $\boldsymbol{E}_{\text {, Quantification of }}$ amyelinated fibers was performed on semithin sections of P28 sciatic nerve. ${ }^{*} p<0.05$ (one-way ANOVA; 5 microscopic fields from $n=3$ animals per genotype). $\boldsymbol{F}, g$ ratio analysis (scatterplot) confirmed hypomyelination in S63del nerves (red) versus WT (blue) and Perk ${ }^{\text {NRNKO }}$ (cyan). In S63del/Perk ${ }^{\text {NRNKO }}$ (pink), myelin remains thin as in S63del. The graph represents the $g$ ratio measured from over 700 myelinated axons (4-5 microscopic fields from $n=3$ animals per genotype). $\boldsymbol{G}, \boldsymbol{H}$, Electrophysiological analysis on P28 sciatic nerves showing NCV $(\boldsymbol{F})$ and distal CMAP amplitude $(\boldsymbol{G}) .{ }^{*} p<0.05 ;{ }^{* *} p<0.01 ;{ }^{* * *} p<0.001$ (one-way AN0VA with Bonferroni's multiple comparison; $n=6-16$ nerves; $\boldsymbol{F}-\boldsymbol{G}$ ). ns, Not significant. Scale bars: $\boldsymbol{B}, \mathrm{a}, \mathrm{a}^{\prime}, 50 \mu \mathrm{m} ; \boldsymbol{B}, \mathrm{a}^{\prime \prime}, \boldsymbol{D}, 10 \mu \mathrm{m} ; \boldsymbol{C}, 20 \mu \mathrm{m}$. Error bars indicate SEM.

tribute axons to sciatic nerves would lack PERK. We then bred S63del onto the Perk ${ }^{\text {NRNKO }}$ background to obtain S63del/ Perk ${ }^{\mathrm{NRNKO}}$ mice.

To test the efficiency of NestinCre-mediated ablation of Perk in neurons, PERK protein levels were detected by Western blot analysis of lumbar spinal cord (Fig. $4 A$ ) and by immunohistochemical analysis in ventral horn neurons (Fig. $4 B$, $a$, black arrowheads). In Perk ${ }^{\text {NRNKO }}$ spinal cord, the level of PERK was significantly reduced in most motor neurons (Fig. $4 A, B, a^{\prime}$ ). Importantly, we demonstrated that the eIF $2 \alpha$ phosphorylation (PERK target; green) was also reduced in DRG sensory neurons (pseudocolor red) of Perk ${ }^{\mathrm{NRNKO}}$, compared to WT (Fig. 4C). Together, these data indicate that PERK levels and kinase function have been effectively reduced in motor and DRG neurons in Perk ${ }^{\text {NRNKO }}$ animals. In contrast, PERK was still easily detected in
Schwann cell cytoplasm of Perk ${ }^{\text {NRNKO }}$ sciatic nerves (Fig. $4 B, a^{\prime \prime}$, yellow arrowheads) confirming that NestinCre is not active in Schwann cells (Kao et al., 2009).

We analyzed myelin morphology and confirmed that S63del nerves show thinner myelin and an increased percentage of amyelinated fibers compared to WT nerves, as described previously (Fig. 4D-F). We did not find substantial differences between S63del and S63del/Perk ${ }^{\text {NRNKO }}$ nerves for either the $g$ ratio (Fig. $4 E ; 0.70 \pm 0.005$ vs $0.70 \pm 0.010$, respectively) or the amount of amyelinated fibers (Fig. 4 E, F). Finally, Perk ablation in neurons did not alter NCV or distal CMAP amplitude of S63del (Fig. 4G,H). These data indicate that deletion of Perk in S63del neurons does not alter axons or myelination in S63del sciatic nerves. 
A

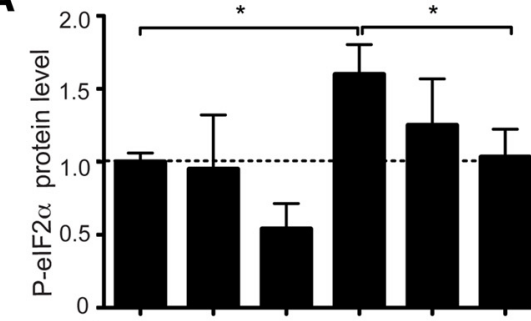

P-elF2 $\alpha$


SCHet SCKO

B

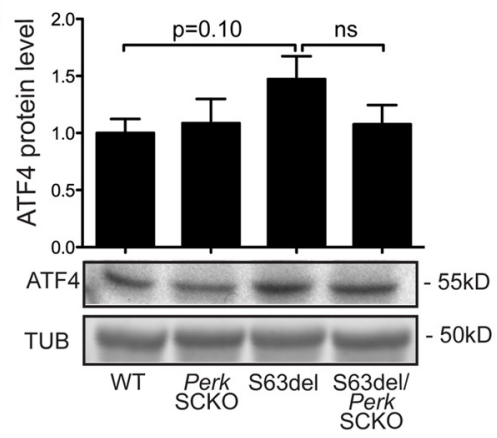

C

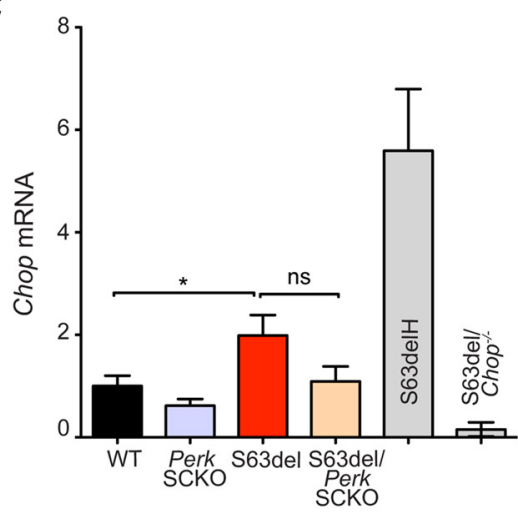

E

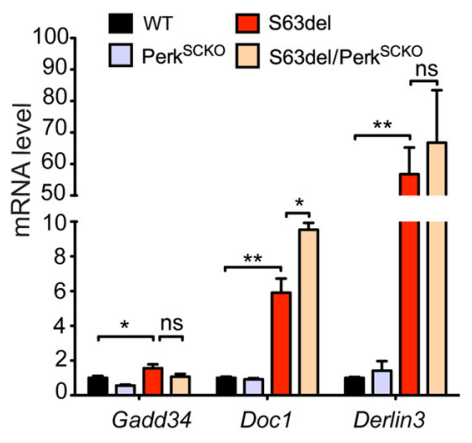

D

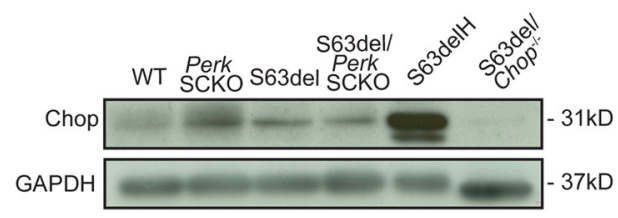

$\mathbf{F}$

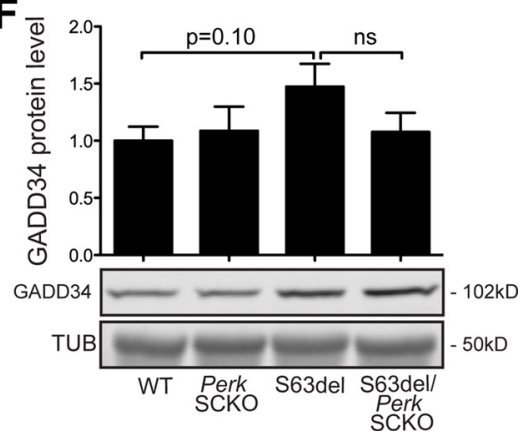

Figure 5. Perk ablation in S63del nerves reduced P-elF2 $\alpha$ but not CHOP activation. $\boldsymbol{A}, \boldsymbol{B}$, Western blot analysis on P28 sciatic nerves for P-elF2 $\alpha$ and ATF4. $\beta$-tubulin (Tub) served as a loading control. $n=4$. C, Chop mRNA levels were measured on P28 sciatic nerves by RT-PCR TaqMan assay, normalized for 18S rRNA. S63delH (high), a different transgenic mouse that overexpresses the P0S63del transgene (210\% expression), was used as positive control; S63del/Chop ${ }^{-1}$ - nerves were used as a negative control. $n=6 \mathrm{RT}$ from three independent sets of nerves of each genotype. D, CHOP protein levels were detected by Western blot analysis on P28 nerves. GAPDH served as a loading control. S63delH and S63del/Chop ${ }^{-1}$ - sciatic nerves were used as positive and negative controls, respectively. One representative out of four independent experiments is shown. $\boldsymbol{E}$, Gadd34, Doc1, and Derlin3 mRNA levels were measured on P28 sciatic nerves by RT-PCR TaqMan assay, normalized for 18S rRNA. $n=3-6$ RT from three independent sets of nerves for each genotype. $F$, GADD34 protein levels were measured by Western blot analysis in P28 sciatic nerves and normalized to $\beta$-tubulin. $n=3 .{ }^{*} p<0.05 ;{ }^{* *} p<0.01$ (Student's $t$ test). ns, Not significant. Error bars indicate SEM.

\section{Perk ablation reduces eIF $2 \alpha$ phosphorylation but not CHOP} activation in 563 del nerves

Upon ER stress, PERK phosphorylates eIF2 $\alpha$ to restore translational homeostasis (Harding et al., 1999, 2000a, 2001a). We showed previously that PERK is the main eIF2 $\alpha$ kinase activated in S63del Schwann cells, and partial ablation of Perk reduced the level of eIF2 $\alpha$ phosphorylation (Musner et al., 2016). Accordingly, we observed that eIF2 $\alpha$ phosphorylation was remarkably reduced in $\mathrm{S} 63 \mathrm{del} /$ Perk $^{\mathrm{SCKO}}$ compared to $\mathrm{S63del}$ nerves (Fig. 5A). This reduction was noticeable also in Perk $^{\mathrm{SCKO}}$ compared to WT control nerves. ATF4 mRNA escapes the translational block caused by P-eIF $2 \alpha$. In fact, ATF 4 synthesis is ER stress dependent, and it decreases upon dephosphorylation of eIF2 $\alpha$ (Harding et al., 2000a). The level of ATF4 was slightly reduced in S63del/Perk ${ }^{\text {SCKO }}$ compared to S63del nerves, although the reduction was not statistically significant (Fig. 5B). Similarly, compared to S63del, Perk deficiency in S63del nerves did not cause a significant reduction of Chop mRNA or its target genes Gadd34, Doc1, and Derlin3 (Fig. 5C,E). Similarly, both CHOP and GADD34 protein levels remained high in S63del/Perk ${ }^{\mathrm{SCKO}}$ compared to S63del (Fig. 5D,F). Notably, we showed previously that only full Chop or Gadd34 ablation (Pennuto et al., 2008; D'Antonio et al., 2013), and not partial Chop ablation (data not shown), was sufficient to improve the S63del phenotype. Collectively, the data indicate that Perk ablation in Schwann cells remarkably diminishes eIF $2 \alpha$ phosphorylation. However, removing Perk in S63del nerves does not alter Chop expression or activation of its target genes, suggesting that Chop does not account for the myelin improvement of S63del/Perk ${ }^{\text {SCKO }}$ nerves.

\section{Improved myelination in S63del/Perk ${ }^{\mathrm{SCKO}}$ nerves is not associated with compensation in the IRE1 $\alpha$ and ATF6 pathways}

IRE $1 \alpha$ and ATF6 contribute to long-lasting adaptation to stress, and the amplification of these pathways is often beneficial upon ER stress. For example, persistent activation of IRE1 $\alpha$ increases cell viability in HEK293 cells treated with tunicamycin or thapsigargin and in stressed neurons in the retina (Lin et al., 2007b). In addition, enhanced IRE1 $\alpha$ expression and ATF6 activation upon stress have been reported in PERK-defective cells (Harding et al., 2000b; Yamaguchi et al., 2008). We therefore wondered whether Perk ablation in S63del Schwann cells might alter ATF6 or IRE1 $\alpha$ signaling. ATF6 activation was estimated by the level of cleaved ATF6 (ATF6c) in nerve lysates from P28 WT, Perk ${ }^{\text {SCKO }}$, S63del, and S63del/Perk ${ }^{\mathrm{SCKO}}$ mice; ATF6c levels in S63del/Perk ${ }^{\mathrm{SCKO}}$ and S63del lysates were comparable (Fig. 6A). ATF6c promotes the expression of ER-resident chaperones, which are highly upregulated upon UPR (Okada et al., 2002; Wu et al., 2007; Yamamoto et al., 2007). Accordingly the expression of GRP94, BIP, and calreticulin were increased in S63del compared to WT mice. However, their levels in S63del/Perk ${ }^{\mathrm{SCKO}}$ and S63del lysates were again similar (Fig. 6B,C), suggesting that the ATF6 pathway is not affected by Perk ablation in S63del Schwann cells.

To detect IRE $1 \alpha$ activation, we measured the phosphorylation state of IRE $1 \alpha$ and the mRNA levels of Xbp1s transcription factor (Yoshida et al., 2001; Calfon et al., 2002; Shen et al., 2002). We noticed an increase in expression of IRE1 $\alpha$ total protein in S63del compared to WT, and the levels remained similarly high in S63del/Perk ${ }^{\text {SCKO }}$ nerves (Fig. $6 D$ ). The separation of P-IRE1 $\alpha$ 




Figure 6. Perk loss of function in Schwann cells does not alter ATF6 or IRE $1 \alpha$ pathways. A, ATF6 precursor form ( $90 \mathrm{kDa}$ ) and ATF6 cleaved form ( $50 \mathrm{kDa}$ ) and were quantified by Western blot analysis in P28 sciatic nerves. GAPDH was used as loading control. $n=3$ lysates from independent pairs of nerves for each genotype. $\boldsymbol{B}$, Bip mRNA was measured by RT-PCR TaqMan assay on P28 sciatic nerves, normalized for 18 S rRNA. $n=6$ RT from three independent sets of nerves for each genotype. C, Bip, Grp94, and calreticulin protein levels were identified by Western blot analysis, and GAPDH was used as loading control. One of five independent experiments is shown. D, IRE $1 \alpha$ protein levels were detected by Western blot analysis. The phosphorylated active form of IRE1 (IRE $1 \alpha-P$ ) was separated from the unphosphorylated and inactive form (IRE1 $\alpha$ ) on a Phos-tag polyacrylamide gel (25 $\mu \mathrm{M})$. One of three independent experiments is shown. Tot, total. $\boldsymbol{E}$, Xbp1 splicing (Xbp1s), ERdj4, and $p 58 / P K$ mRNA levels were measured by RT-PCR TaqMan assay on P28 sciatic nerves, normalized for 185 rRNA. $n=2-6$ RT from three or four independent sets of nerves for each genotype. ${ }^{*} p<0.05 ;{ }^{* *} p<0.01$ (Student's $t$ test). Error bars indicate SEM.

from nonphosphorylated IRE1 $\alpha$ was achieved by using the Phostag compound (Martinon et al., 2010; Yang et al., 2010). P-IRE1 $\alpha$ levels increased in S63del compared to WT nerves, and the levels did not increase further in S63del/Perk ${ }^{\text {SCKO }}$ nerves (Fig. $6 D$ ). Accordingly, Xbp 1s mRNA did not increase in S63del/Perk ${ }^{\text {SCKO }}$ compared to S63del nerves (Fig. 6E). Moreover, the expression of XBP1s-dependent ER enzymes, such as ERdj4 and $p 58^{I P K}$ (Lee et al., 2003), was induced in S63del nerves and remained high in S63del/Perk ${ }^{\text {SCKO }}$ nerves (Fig. 6E). Collectively, these data show that the UPR is activated in S63del/Perk ${ }^{\mathrm{SCKO}}$ nerves similarly to S63del nerves. In addition, IRE1 $\alpha$ and ATF6 pathways are not significantly altered in S63del/Perk ${ }^{\mathrm{SCKO}}$ nerves, which suggests that compensation within the UPR does not account for the ameliorated myelination observed in S63del/Perk ${ }^{\mathrm{SCKO}}$ nerves.
P0 is retained at similar levels in the ER of S63del and S63del/Perk ${ }^{\text {SCKO }}$ Schwann cells

The retention of P0S63del protein in the ER of Schwann cells triggers the UPR and causes the CMT1B neuropathy, and levels of P0 engulfment in the ER of Schwann cells is a direct measure of beneficial response (Wrabetz et al., 2006; Pennuto et al., 2008; D'Antonio et al., 2013). We showed that Perk elimination in S63del Schwann cells improves myelination without a substantial reduction of the UPR markers. Overall, our data indicate that these Schwann cells are subjected to persistent ER stress. Thus, we asked whether, despite the ongoing UPR, Perk ablation could reduce the amount of $\mathrm{P} 0$ in the ER and improve the proteostasis in S63del Schwann cells. We found that P0 colocalized with KDEL, marker of the ER, in both S63del and S63del/Perk ${ }^{\text {SCKO }}$ 
A

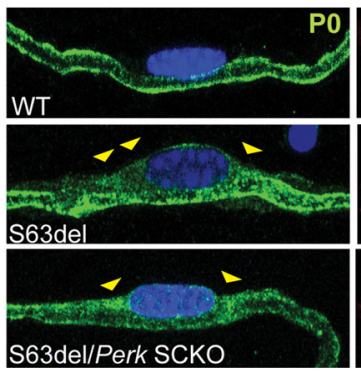

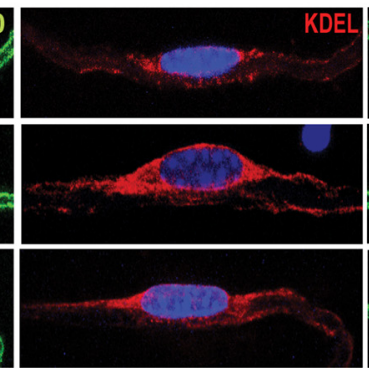

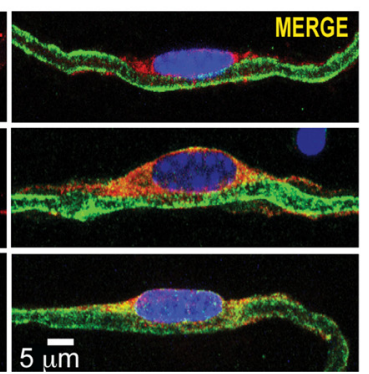

B

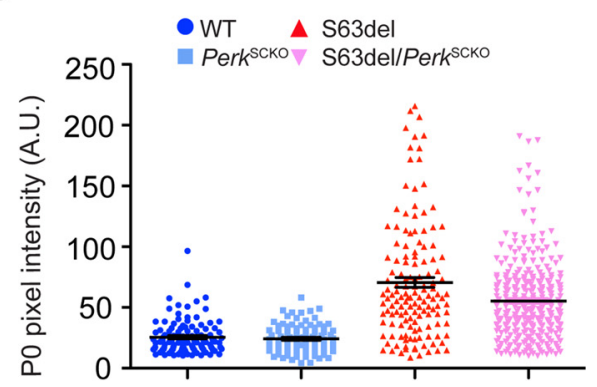

Figure 7. PO is retained at similar levels in the ER of S63del and S63del/Perk ${ }^{\mathrm{SCK} 0}$ Schwann cells. $\boldsymbol{A}$, Immunofluorescence for P0 (green) and KDEL (red) in teased fibers from P28 sciatic nerves revealed PO localization in the endoplasmic reticulum of Schwann cells (yellow arrowheads). Nuclei were stained in blue (DAPI). Scale bar, $5 \mu \mathrm{m}$. $\boldsymbol{B}, \mathrm{The}$ range of P0 pixel intensity was quantified within the KDEL area. Error bars indicate SD. $n=100-300$ fibers from three or four different nerves for each genotype. A.U., Arbitrary unit.

teased fibers from P28 sciatic nerves (Fig. 7A, yellow arrowheads). The quantification of $\mathrm{P} 0$ pixel intensity within the KDEL area revealed lower levels of P0 colocalizing with KDEL in control nerves (Fig. $7 B$, blue and cyan dots). The amount of P0 localized in the ER was similarly greater in S63del and S63del/Perk ${ }^{\text {SCKO }}$ Schwann cells (Fig. $7 B$, red and pink dots), clearly suggesting that P0 remains persistently retained in S63del/Perk ${ }^{\text {SCKO }}$ Schwann cells. These data demonstrate that Perk ablation does not alleviate the ER overload in S63del Schwann cells and P0 retention likely contributes to the persistent UPR.

\section{Discussion}

Here we characterized S63del/Perk ${ }^{\mathrm{SCKO}}$ and S63del/Perk ${ }^{\mathrm{NRNKO}}$ mice and showed that ablation of Perk in Schwann cells but not in neurons improves CMT1B neuropathy in mice. The improvement occurs despite a reduction in P-eIF $2 \alpha$. We also explored the signals downstream of PERK and the other UPR arms to identify any compensatory mechanism responsible for the surprising improvement, but found no evident changes. Comparing our data with the Gadd34-null amelioration of the S63del phenotype (D'Antonio et al., 2013), we conclude that UPR and translational homeostasis are not the only pathogenetic mechanisms involved in CMT1B-S63del Schwann cells. PERK, in fact, may interfere with other pathways outside of the UPR in S63del Schwann cells.

\section{Improvement in S63del Schwann cells does not necessarily correlate with increased eIF $2 \alpha$ phosphorylation}

Here we show for the first time that a context with reduction of P-eIF2 $\alpha$ specifically in Schwann cells can improve, rather than worsen, the myelin defect of S63del nerves. Our result seems to differ from other studies where perturbing the PERK P-eIF2 $\alpha$ pathway has been shown to be extremely detrimental in different ER stress settings. For instance, Perk ${ }^{-/-}$and eIF $2 \alpha^{\mathrm{A} / \mathrm{A}}$ (not phosphorylatable) mice exhibit a significant reduction in the number of pancreatic cells, failure of hepatocytes to produce glycogen, and reduced osteoblast differentiation and collagen secretion (Harding et al., 2000a,b; Scheuner et al., 2001; Zhang et al., 2002; Wei et al., 2008; Saito et al., 2011). Mutations in human PERK result in Walcott-Rallison syndrome, associated with neonatal type I diabetes (Thornton et al., 1997; Rubio-Cabezas et al., 2009). Moreover, PERK-eIF2 $\alpha$ function has been shown to promote neuroprotection in neurodegenerative disease models like Parkinson's disease and ALS (Wang et al., 2011; Colla et al., 2012).

Likewise, in myelin-related disorders, loss of function mutations in eIF2B, the target of $\mathrm{P}$-eIF $2 \alpha$ regulation, results in vanishing white matter disease, and Perk haploinsufficiency worsens the clinical outcome in the experimental allergic encephalomyelitis model of multiple sclerosis (Proud, 2001; Lin et al., 2007b). In agreement with these observations, reinforcing P-eIF $2 \alpha$ in S63del peripheral demyelinating neuropathy, by genetically or pharmacologically impairing GADD34, rescues morphological and functional deficits in S63del nerves (D'Antonio et al., 2013; Das et al., 2015). Inhibiting GADD34 function increases the level of P-eIF2 $\alpha$, limits protein translation, reduces ER overload, and ultimately relieves S63del Schwann cells of chronic UPR. These data strongly suggest that reducing translation is sufficient to restore myelination in S63del neuropathy. Schwann cells rely on phosphorylation of eIF $2 \alpha$ to achieve and maintain functional myelination in the face of persistent ER stress (D'Antonio et al., 2013).

\section{The detrimental effect of Perk in CMT1B derives from Schwann cells}

S63del nerves exhibit specific features that suggest a Schwanncell-derived neuropathy (Wrabetz et al., 2006). For instance, at P28, myelin appears thinner and the number of amyelinating axons is increased compared to WT, suggesting a delay in Schwann cell development. Moreover, the NCV is reduced and the F-wave latency increased, which are hallmarks of demyelinating neuropathy. Interestingly, the distal CMAP is also reduced, indicating that the motor nerve action potential might be impaired due to the loss of axons or conduction block, a matter for further investigation.

We showed previously that reducing P-eIF $2 \alpha$ by altering Perk dosage in S63del mice partially ameliorates the motor performance and demyelinating phenotype of S63del neuropathy (Musner et al., 2016). In that study, we eliminated one Perk allele in every cell of the S63del mouse, including brain, muscle, and pancreas, that could affect the motor performance (Musner et al., 2016). Nonetheless, there were no gross abnormalities in the cytoarchitecture of these tissues, suggesting that they did not contribute to the impaired motor performance. Moreover, Perknull S63del neurons did not improve myelination in neuronal/ Schwann cell cocultures, suggesting that activation of PERK in S63del neurons did not provoke aberrant S63del myelination (Musner et al., 2016). Here, we aimed to fully understand the role of Perk in S63del mice by asking whether Perk is detrimental in Schwann cells or neurons.

To directly address this question in S63del nerves, we eliminated Perk cell-specifically by taking advantage of a Cre-loxP strategy. Perk loss of function in normal Schwann cells does not impair physiological myelination. However, in pathological nerves, the absence of Perk specifically in Schwann cells results in 
the amelioration of S63del myelin defects. In S63del/Perk ${ }^{\text {SCKO }}$ nerves, myelin thickness is increased, and the number of amyelinated axons is remarkably reduced compared to S63del. Furthermore, NCV is slightly improved, confirming that Perk ablation reversed hypomyelination. F-wave latency and distal CMAP are not restored to normal.

These data differ from those in our previous work, where Perk haploinsufficiency was not sufficient to improve myelin thickness and NCV (Musner et al., 2016). Beside Perk dosage and the extent of tissues in which Perk was ablated, other possible explanations for the difference include that the prior experiments were performed in 4-month-old animals in the FVB/N background, whereas the experiments here were performed in 1-month-old animals in the C57BL/ 6 background. In any case, the data here indicate that PERK, like CHOP and GADD34, contributes to the S63del neuropathic mechanism. Moreover, they show for the first time that the detrimental effect of the PERK pathway derives from Schwann cells.

Conversely, the ablation of Perk in neurons does not alter CMT1B neuropathy. In fact, neither myelination nor electrophysiological values were improved in S63del/Perk ${ }^{\text {NRNKO }}$ co- $^{-}$ mpared to S63del nerves. Using NestinCre, PERK and eIF2 $\alpha$-P levels were reduced in motor and DRG neurons, respectively, indicating that neurons that contribute axons to sciatic nerves were appropriately targeted in S63del/Perk ${ }^{\text {NRNKO }}$ animals. Other glia in the CNS are also targeted, but it is unlikely that this can explain the lack of phenotype in neurons. These data demonstrate that the detrimental role of Perk in CMT1B derives mainly from Schwann cells. Interestingly, the ablation of Perk in WT neurons slightly reduced the NCV and distal CMAP amplitude, suggesting a potentially beneficial role of Perk in normal neuronal function.

\section{ER stress markers do not change upon Perk ablation in Schwann cells}

To elucidate how Perk ablation ameliorates rather then worsens hypomyelination in S63del, we surveyed the UPR pathways. CHOP ablation in S63del mice strongly rescues neuropathy (Pennuto et al., 2008; D’Antonio et al., 2013). However, we found that CHOP protein level and target genes were still upregulated in S63del/Perk ${ }^{\text {SCKO }}$ nerves similarly to S63del. This result indicates that CHOP is active in $\mathrm{S} 63 \mathrm{del} /$ Perk $^{\mathrm{SCKO}}$ nerves and cannot account for the $\mathrm{S} 63 \mathrm{del} /$ Perk $^{\mathrm{SCKO}}$ myelin phenotype. Our findings are also consistent with the idea that CHOP can be activated by other UPR pathways, like ATF6 (Yoshida et al., 2001). In Perk $^{-1-}$ ES cells, IRE1 activation is prolonged, and cells stably transfected with a dominant-negative form of PERK show enhanced ATF6 activation when challenged with tunicamycin (Harding et al., 2000b; Yamaguchi et al., 2008). Moreover, persistent activation of IRE1 promotes cell viability upon stress (Lin et al., 2007a). Hence, we hypothesized that perturbing Perk in S63del Schwann cells may trigger a beneficial compensatory response from the ATF6 or IRE1 arms. However, we found none of the main effectors of these two pathways were altered, indicating that IRE1 and ATF6 signals are not likely to compensate for Perk loss of function.

\section{The effects of PERK and eIF2 $\alpha$ are uncoupled}

The scenarios described previously in S63del/GADD34 ${ }^{\Delta \mathrm{C} / \Delta \mathrm{C}}$ mice and here in S63del/Perk ${ }^{\mathrm{SCKO}}$ mice differ. GADD34 loss of function improves $\mathrm{S} 63$ del myelination by reducing the accumulation of P0 in the ER of Schwann cells, which alleviates ER stress and UPR signaling (D'Antonio et al., 2013), whereas Perk abla- tion in Schwann cells ameliorates S63del myelination even if misfolded proteins in the ER and UPR remain. In other words, Perk ablation in Schwann cells alleviates the neuropathy without reverting the toxic pathological mechanism. Moreover, we find no evidence to suggest compensation from other parallel pathways of the UPR. This suggests that the UPR might not be the only pathological mechanism involved in CMT1B-S63del Schwann cells.

We propose that PERK might have P-eIF2 $\alpha$-independent effects in neuropathy, possibly through alternative pathways. For instance, there is evidence that PERK targets additional substrates to eIF2 $\alpha$, like the Nrf2 transcription factor and Mfn2, a mitochondrial protein that regulates ER morphology and $\mathrm{Ca}^{2+}$ flux between ER and mitochondria (Cullinan et al., 2003; Munoz et al., 2013). There may be other unrecognized PERK targets also in Schwann cells involved in metabolism and myelination.

Accordingly, other studies have suggested that PERK exerts a detrimental role in ER stress-related diseases, where the effect of Perk seems to be uncoupled from attenuation of translation. Perk haploinsufficiency slows the progression of diabetes in Akita mice probably by modulating ER associated degradation and degradation of proinsulin (Gupta et al., 2010). Pharmacological inhibition of PERK and reduction of P-eIF $2 \alpha$ prevents the clinical outbreak of prion disease without altering the level of $\operatorname{PrP}^{\mathrm{Sc}}$ in prion infected mice (Moreno et al., 2013). $\operatorname{PrP}^{\mathrm{Sc}}$ mRNA carries several upstream open reading frames that allow it to escape the translational attenuation caused by $\operatorname{eIF} 2 \alpha$ phosphorylation. Therefore, reducing P-eIF $2 \alpha$ may actually reduce the synthesis of $\mathrm{PrP}^{\mathrm{Sc}}$ in prion-infected mice (Moreno et al., 2012). PERK inhibition also reduces the neuronal toxicity of TDP-43 RNAbinding protein in a fly model of ALS (Kim et al., 2014). In this example, the increased level of P-eIF $2 \alpha$ and resulting translational attenuation are thought to promote TDP-43 induced neuronal toxicity. Finally, transgenic mice with neurodegeneration due to overexpression of mutant tau protein may provide a similar example (Radford et al., 2015). These last three examples are similar to S63del mice and support a beneficial effect of Perk inhibition in neurodegenerative diseases. However, unlike the S63del mice where P-eIF2 $\alpha$ is protective (D'Antonio et al., 2013), the proteotoxicity of PrP, TDP-43 and mutant tau is directly correlated to the increased level of P-eIF $2 \alpha$. This strongly supports that the mechanism responsible for S63del/Perk ${ }^{\text {SCKO }}$ improvement is uncoupled from $\mathrm{P}$-eIF $2 \alpha$. Experiments to specifically eliminate P-eIF $2 \alpha$ in Schwann cells without altering PERK signaling (Back et al., 2009) and a search for other PERK targets in Schwann cells will address this hypothesis.

\section{References}

Back SH, Scheuner D, Han J, Song B, Ribick M, Wang J, Gildersleeve RD, Pennathur S, Kaufman RJ (2009) Translation attenuation through eIF2alpha phosphorylation prevents oxidative stress and maintains the differentiated state in beta cells. Cell Metab 10:13-26. CrossRef Medline

Bertolotti A, Ron D (2001) Alterations in an IRE1-RNA complex in the mammalian unfolded protein response. J Cell Sci 114:3207-3212. Medline

Calfon M, Zeng H, Urano F, Till JH, Hubbard SR, Harding HP, Clark SG, Ron D (2002) IRE1 couples endoplasmic reticulum load to secretory capacity by processing the XBP-1 mRNA. Nature 415:92-96. CrossRef Medline

Colla E, Jensen PH, Pletnikova O, Troncoso JC, Glabe C, Lee MK (2012) Accumulation of toxic alpha-synuclein oligomer within endoplasmic reticulum occurs in alpha-synucleinopathy in vivo. J Neurosci 32: 3301-3305. CrossRef Medline

Cullinan SB, Zhang D, Hannink M, Arvisais E, Kaufman RJ, Diehl JA (2003) Nrf2 is a direct PERK substrate and effector of PERK-dependent cell survival. Mol Cell Biol 23:7198-7209. CrossRef Medline

D’Antonio M, Musner N, Scapin C, Ungaro D, Del Carro U, Ron D, Feltri 
ML, Wrabetz L (2013) Resetting translational homeostasis restores myelination in Charcot-Marie-Tooth disease type 1B mice. J Exp Med 210: 821-838. CrossRef Medline

Das I, Krzyzosiak A, Schneider K, Wrabetz L, D’Antonio M, Barry N, Sigurdardottir A, Bertolotti A (2015) Preventing proteostasis diseases by selective inhibition of a phosphatase regulatory subunit. Science 348: 239-242. CrossRef Medline

de Waegh SM, Lee VM, Brady ST (1992) Local modulation of neurofilament phosphorylation, axonal caliber, and slow axonal transport by myelinating Schwann cells. Cell 68:451-463. CrossRef Medline

Feltri ML, D’Antonio M, Previtali S, Fasolini M, Messing A, Wrabetz L (1999) P0-Cre transgenic mice for inactivation of adhesion molecules in Schwann cells. Ann N Y Acad Sci 883:116-123. CrossRef

Fratta P, Saveri P, Zambroni D, Ferri C, Tinelli E, Messing A, D’Antonio M, Feltri ML, Wrabetz L (2011) P0S63del impedes the arrival of wild-type P0 glycoprotein to myelin in CMT1B mice. Hum Mol Genet 20: 2081-2090. CrossRef Medline

Friedlander R, Jarosch E, Urban J, Volkwein C, Sommer T (2000) A regulatory link between ER-associated protein degradation and the unfoldedprotein response. Nat Cell Biol 2:379-384. CrossRef Medline

Gupta S, McGrath B, Cavener DR (2010) PERK (EIF2AK3) regulates proinsulin trafficking and quality control in the secretory pathway. Diabetes 59:1937-1947. CrossRef Medline

Harding HP, Zhang Y, Ron D (1999) Protein translation and folding are coupled by an endoplasmic-reticulum-resident kinase. Nature 397: 271-274. CrossRef Medline

Harding HP, Novoa I, Zhang Y, Zeng H, Wek R, Schapira M, Ron D (2000a) Regulated translation initiation controls stress-induced gene expression in mammalian cells. Mol Cell 6:1099-1108. CrossRef Medline

Harding HP, Zhang Y, Bertolotti A, Zeng H, Ron D (2000b) Perk is essential for translational regulation and cell survival during the unfolded protein response. Mol Cell 5:897-904. CrossRef Medline

Harding HP, Novoa I, Bertolotti A, Zeng H, Zhang Y, Urano F, Jousse C, Ron D (2001a) Translational regulation in the cellular response to biosynthetic load on the endoplasmic reticulum. Cold Spring Harb Symp Quant Biol 66:499-508. CrossRef Medline

Harding HP, Zeng H, Zhang Y, Jungries R, Chung P, Plesken H, Sabatini DD, Ron D (2001b) Diabetes mellitus and exocrine pancreatic dysfunction in perk $-/-$ mice reveals a role for translational control in secretory cell survival. Mol Cell 7:1153-1163. CrossRef Medline

Haze K, Yoshida H, Yanagi H, Yura T, Mori K (1999) Mammalian transcription factor ATF6 is synthesized as a transmembrane protein and activated by proteolysis in response to endoplasmic reticulum stress. Mol Biol Cell 10:3787-3799. CrossRef Medline

Hetz C, Chevet E, Harding HP (2013) Targeting the unfolded protein response in disease. Nat Rev Drug Discov 12:703-719. CrossRef Medline

Kao SC, Wu H, Xie J, Chang CP, Ranish JA, Graef IA, Crabtree GR (2009) Calcineurin/NFAT signaling is required for neuregulin-regulated Schwann cell differentiation. Science 323:651-654. CrossRef Medline

Kim HJ, Raphael AR, LaDow ES, McGurk L, Weber RA, Trojanowski JQ, Lee VM, Finkbeiner S, Gitler AD, Bonini NM (2014) Therapeutic modulation of eIF2alpha phosphorylation rescues TDP-43 toxicity in amyotrophic lateral sclerosis disease models. Nat Genet 46:152-160. Medline

Kulkens T, Bolhuis PA, Wolterman RA, Kemp S, te Nijenhuis S, Valentijn LJ, Hensels GW, Jennekens FG, de Visser M, Hoogendijk JE, Baas F (1993) Deletion of the serine 34 codon from the major peripheral myelin protein P0 gene in Charcot-Marie-Tooth disease type 1B. Nat Genet 5:35-39. CrossRef Medline

Lee AH, Iwakoshi NN, Glimcher LH (2003) XBP-1 regulates a subset of endoplasmic reticulum resident chaperone genes in the unfolded protein response. Mol Cell Biol 23:7448-7459. CrossRef Medline

Lin JH, Li H, Yasumura D, Cohen HR, Zhang C, Panning B, Shokat KM, Lavail MM, Walter P (2007a) IRE1 signaling affects cell fate during the unfolded protein response. Science 318:944-949. CrossRef Medline

Lin W, Bailey SL, Ho H, Harding HP, Ron D, Miller SD, Popko B (2007b) The integrated stress response prevents demyelination by protecting oligodendrocytes against immune-mediated damage. J Clin Invest 117: 448-456. CrossRef Medline

Martinon F, Chen X, Lee AH, Glimcher LH (2010) TLR activation of the transcription factor XBP1 regulates innate immune responses in macrophages. Nat Immunol 11:411-418. CrossRef Medline

Miller LJ, Patzko A, Lewis RA, Shy ME (2012) Phenotypic presentation of the Ser63Del MPZ mutation. J Peripher Nerv Syst 17:197-200. CrossRef Medline

Moreno JA, Radford H, Peretti D, Steinert JR, Verity N, Martin MG, Halliday M, Morgan J, Dinsdale D, Ortori CA, Barrett DA, Tsaytler P, Bertolotti A, Willis AE, Bushell M, Mallucci GR (2012) Sustained translational repression by eIF2alpha-P mediates prion neurodegeneration. Nature 485: 507-511. Medline

Moreno JA, Halliday M, Molloy C, Radford H, Verity N, Axten JM, Ortori CA, Willis AE, Fischer PM, Barrett DA, Mallucci GR (2013) Oral treatment targeting the unfolded protein response prevents neurodegeneration and clinical disease in prion-infected mice. Sci Transl Med 5:206ra138. Medline

Munoz JP, Ivanova S, Sánchez-Wandelmer J, Martínez-Cristóbal P, Noguera E, Sancho A, Díaz-Ramos A, Hernández-Alvarez MI, Sebastián D, Mauvezin C, Palacín M, Zorzano A (2013) Mfn2 modulates the UPR and mitochondrial function via repression of PERK. EMBO J 32:2348-2361. CrossRef Medline

Musner N, Sidoli M, Zambroni D, Del Carro U, Ungaro D, D’Antonio M, Feltri ML, Wrabetz L (2016) Perk ablation ameliorates myelination in S63del-CharcotMarie-Tooth 1B neuropathy. ASN Neuro 8:1-18. Medline

Novoa I, Zeng H, Harding HP, Ron D (2001) Feedback inhibition of the unfolded protein response by GADD34-mediated dephosphorylation of eIF2alpha. J Cell Biol 153:1011-1022. CrossRef Medline

Okada T, Yoshida H, Akazawa R, Negishi M, Mori K (2002) Distinct roles of activating transcription factor 6 (ATF6) and double-stranded RNAactivated protein kinase-like endoplasmic reticulum kinase (PERK) in transcription during the mammalian unfolded protein response. Biochem J 366:585-594. CrossRef Medline

Patzig J, Jahn O, Tenzer S, Wichert SP, de Monasterio-Schrader P, Rosfa S, Kuharev J, Yan K, Bormuth I, Bremer J, Aguzzi A, Orfaniotou F, Hesse D, Schwab MH, Möbius W, Nave KA, Werner HB (2011) Quantitative and integrative proteome analysis of peripheral nerve myelin identifies novel myelin proteins and candidate neuropathy loci. J Neurosci 31:1636916386. CrossRef Medline

Pennuto M, Tinelli E, Malaguti M, Del Carro U, D'Antonio M, Ron D, Quattrini A, Feltri ML, Wrabetz L (2008) Ablation of the UPR-mediator $\mathrm{CHOP}$ restores motor function and reduces demyelination in CharcotMarie-Tooth 1B mice. Neuron 57:393-405. CrossRef Medline

Proud CG (2001) Regulation of eukaryotic initiation factor eIF2B. Prog Mol Subcell Biol 26:95-114. CrossRef Medline

Quattrini A, Previtali S, Feltri ML, Canal N, Nemni R, Wrabetz L (1996) Beta 4 integrin and other Schwann cell markers in axonal neuropathy. Glia 17:294-306. CrossRef Medline

Radford H, Moreno JA, Verity N, Halliday M, Mallucci GR (2015) PERK inhibition prevents tau-mediated neurodegeneration in a mouse model of frontotemporal dementia. Acta Neuropathol 130:633-642. CrossRef Medline

Rubio-Cabezas O, Patch AM, Minton JA, Flanagan SE, Edghill EL, Hussain K, Balafrej A, Deeb A, Buchanan CR, Jefferson IG, Mutair A, Hattersley AT, Ellard S (2009) Wolcott-Rallison syndrome is the most common genetic cause of permanent neonatal diabetes in consanguineous families. J Clin Endocrinol Metab 94:4162-4170. CrossRef Medline

Saito A, Ochiai K, Kondo S, Tsumagari K, Murakami T, Cavener DR, Imaizumi K (2011) Endoplasmic reticulum stress response mediated by the PERK-eIF2(alpha)-ATF4 pathway is involved in osteoblast differentiation induced by BMP2. J Biol Chem 286:4809-4818. CrossRef Medline

Scheuner D, Song B, McEwen E, Liu C, Laybutt R, Gillespie P, Saunders T, Bonner-Weir S, Kaufman RJ (2001) Translational control is required for the unfolded protein response and in vivo glucose homeostasis. Mol Cell 7:1165-1176. CrossRef Medline

Schröder M, Kaufman RJ (2005) The mammalian unfolded protein response. Annu Rev Biochem 74:739-789. CrossRef Medline

Shen J, Chen X, Hendershot L, Prywes R (2002) ER stress regulation of ATF6 localization by dissociation of BiP/GRP78 binding and unmasking of Golgi localization signals. Dev Cell 3:99-111. CrossRef Medline

Sherman DL, Brophy PJ (2005) Mechanisms of axon ensheathment and myelin growth. Nat Rev Neurosci 6:683-690. CrossRef Medline

Sriburi R, Jackowski S, Mori K, Brewer JW (2004) XBP1: a link between the unfolded protein response, lipid biosynthesis, and biogenesis of the endoplasmic reticulum. J Cell Biol 167:35-41. CrossRef Medline

Tabas I, Ron D (2011) Integrating the mechanisms of apoptosis induced by endoplasmic reticulum stress. Nat Cell Biol 13:184-190. CrossRef Medline 
Thornton CM, Carson DJ, Stewart FJ (1997) Autopsy findings in the WolcottRallison syndrome. Pediatr Pathol Lab Med 17:487-496. CrossRef Medline

Travers KJ, Patil CK, Wodicka L, Lockhart DJ, Weissman JS, Walter P (2000) Functional and genomic analyses reveal an essential coordination between the unfolded protein response and ER-associated degradation. Cell 101:249-258. CrossRef Medline

Tronche F, Kellendonk C, Kretz O, Gass P, Anlag K, Orban PC, Bock R, Klein R, Schütz G (1999) Disruption of the glucocorticoid receptor gene in the nervous system results in reduced anxiety. Nat Genet 23:99-103. CrossRef Medline

Walter P, Ron D (2011) The unfolded protein response: from stress pathway to homeostatic regulation. Science 334:1081-1086. CrossRef Medline

Wang L, Popko B, Roos RP (2011) The unfolded protein response in familial amyotrophic lateral sclerosis. Hum Mol Genet 20:1008-1015. CrossRef Medline

Wei J, Sheng X, Feng D, McGrath B, Cavener DR (2008) PERK is essential for neonatal skeletal development to regulate osteoblast proliferation and differentiation. J Cell Physiol 217:693-707. CrossRef Medline

Wrabetz L, Feltri ML, Quattrini A, Imperiale D, Previtali S, D’Antonio M, Martini R, Yin X, Trapp BD, Zhou L, Chiu SY, Messing A (2000) P(0) glycoprotein overexpression causes congenital hypomyelination of peripheral nerves. J Cell Biol 148:1021-1034. CrossRef Medline

Wrabetz L, D'Antonio M, Pennuto M, Dati G, Tinelli E, Fratta P, Previtali S, Imperiale D, Zielasek J, Toyka K, Avila RL, Kirschner DA, Messing A, Feltri ML, Quattrini A (2006) Different intracellular pathomechanisms produce diverse Myelin Protein Zero neuropathies in transgenic mice. J Neurosci 26:2358-2368. CrossRef Medline

Wu J, Rutkowski DT, Dubois M, Swathirajan J, Saunders T, Wang J, Song B, Yau GD, Kaufman RJ (2007) ATF6alpha optimizes long-term endoplasmic reticulum function to protect cells from chronic stress. Dev Cell 13:351-364. CrossRef Medline

Yamaguchi Y, Larkin D, Lara-Lemus R, Ramos-Castañeda J, Liu M, Arvan P (2008) Endoplasmic reticulum (ER) chaperone regulation and survival of cells compensating for deficiency in the ER stress response kinase, PERK. J Biol Chem 283:17020-17029. CrossRef Medline
Yamamoto K, Sato T, Matsui T, Sato M, Okada T, Yoshida H, Harada A, Mori K (2007) Transcriptional induction of mammalian ER quality control proteins is mediated by single or combined action of ATF6alpha and XBP1. Dev Cell 13:365-376. CrossRef Medline

Yang L, Xue Z, He Y, Sun S, Chen H, Qi L (2010) A Phos-tag-based approach reveals the extent of physiological endoplasmic reticulum stress. PLoS One 5:e11621. CrossRef Medline

Yoshida H, Okada T, Haze K, Yanagi H, Yura T, Negishi M, Mori K (2000) ATF6 activated by proteolysis binds in the presence of NF-Y (CBF) directly to the cis-acting element responsible for the mammalian unfolded protein response. Mol Cell Biol 20:6755-6767. CrossRef Medline

Yoshida H, Matsui T, Yamamoto A, Okada T, Mori K (2001) XBP1 mRNA is induced by ATF6 and spliced by IRE1 in response to ER stress to produce a highly active transcription factor. Cell 107:881-891. CrossRef Medline

Yoshida H, Matsui T, Hosokawa N, Kaufman RJ, Nagata K, Mori K (2003) A time-dependent phase shift in the mammalian unfolded protein response. Dev Cell 4:265-271. CrossRef Medline

Zhang P, McGrath B, Li S, Frank A, Zambito F, Reinert J, Gannon M, Ma K, McNaughton K, Cavener DR (2002) The PERK eukaryotic initiation factor 2 alpha kinase is required for the development of the skeletal system, postnatal growth, and the function and viability of the pancreas. Mol Cell Biol 22:3864-3874. CrossRef Medline

Zhang W, Feng D, Li Y, Iida K, McGrath B, Cavener DR (2006) PERK EIF2AK3 control of pancreatic beta cell differentiation and proliferation is required for postnatal glucose homeostasis. Cell Metab 4:491-497. CrossRef Medline

Zimmerman L, Parr B, Lendahl U, Cunningham M, McKay R, Gavin B, Mann J, Vassileva G, McMahon A (1994) Independent regulatory elements in the nestin gene direct transgene expression to neural stem cells or muscle precursors. Neuron 12:11-24. CrossRef Medline

Zinszner H, Kuroda M, Wang X, Batchvarova N, Lightfoot RT, Remotti H, Stevens JL, Ron D (1998) CHOP is implicated in programmed cell death in response to impaired function of the endoplasmic reticulum. Genes Dev 12:982-995. CrossRef Medline 